\title{
What Motivates Parents to Participate in Their Child's Brain Gym Therapy
}

\author{
Nadhira Rakhmi Yusuf ${ }^{\left.1^{*}\right)}$, Zainal Abidin ${ }^{2}$ \\ ${ }^{1,2}$ Fakultas Psikologi Universitas Padjadjaran \\ *Corresponding author, e-mail: nadhira18005@mail.unpad.ac.id
}

Received August 02, 2021; Revised August 31, 2021; Accepted Sept. 20, 2021; Published Online 2021-10-01

\section{Conflict of Interest Disclosures:}

The authors declare that they have no significant competing financial, professional or personal interests that might have influenced the performance or presentation of the work described in this manuscript.

\begin{abstract}
The findings in the clinical practice field indicate problems related to the inconsistency of parental participation in the therapy that the child undergoes, namely the absence of parents according to the schedule, nonadherence to the therapist's advice, and premature termination. It raises questions of parents' motivation to participate in their children's therapy while no research in Indonesia examines this topic. The current study aims to understand the description of parents' motivation to participate in their child therapy. This qualitative study was conducted by interviewing 3 mothers (age 23-36 years) whose children (age 3-5 years) undergo brain gym therapy at a psychology bureau in Bandung. They are from the same socioeconomic class, have joined the therapy program for at least one month, and were selected using the purposive sampling technique. The results indicate that the underlying motivation for parental participation in child therapy is parents' need for a change in the child's condition and parents' expectation of the therapeutic outcome. Therapy results that match expectations and positive responses from the environment act as reinforcers that make parents willing to continue participating in child therapy.
\end{abstract}

Keywords: child therapy, parent motivation, participation in therapy.

\section{Introduction}

Childhood is a significant period in the human life span, where a child develops and learns numerous new skills as the basis for the next period of growth. However, several problems can interfere with children's development, i.e., intelligence problems, learning disorders, language disorders, and emotional disorders. Based on statistical data from the Centers for Disease Control and Prevention (2019), 1 in 6 children in America is diagnosed with psychological problems. Meanwhile, according to Koran Jakarta (2017), about $50 \%$ of children in Indonesia are known to have psychological problems. It shows that there is a need in society to overcome psychological problems in children. To overcome these psychological problems an intervention such as brain gym therapy is needed so children can have a more optimal and age-appropriate 
development. In this therapy, clients should not only accept the given treatment but should participate actively, the client's motivation to participate is an essential factor related to the outcome of the therapy (Drieschner, Lammers, \& Van Der Staak, 2004; Gill et al., 2014; Krause, 1966).

Unfortunately, approximately $40-60 \%$ of pediatric therapy ends prematurely (Kazdin, Holland, \& Crowley, 1997; Pellerin, Costa, Weems, \& Dalton, 2010; Wierzbicki \& Pekarik, 1993), or discontinuation of therapy sessions before the required number of sessions without consent from the therapist. In Indonesia, several psychologists interviewed by researchers stated that some parents stopped taking their children to therapy even though the sessions had not been completed, and some parents did not bring their children to attend the therapy process regularly. In addition to attendance, some parents also do not accomplish the advice or duties from the therapist that the child's development is not as optimal as it should be. It also stated that the parents' inconsistency in bringing their children to therapy could cause the child's condition development to be not optimal. In addition, therapy that ends prematurely has the potential to cause the child's problems to worsen. It indicates a crucial need to predict the factors that cause the low participation of parents in child therapy.

Parental participation in child therapy is substantial because it is different from adults who can be responsible independently, children are very dependent on parents because parents are the ones who have responsibility for the child's routine to come to the place and therapy in implementing the therapist's advice. Therefore, in child therapy, parental motivation is the most significant factor to predict the possibility of parental participation in the child's therapy. Motivation to participate in therapy refers to the client-in this case, the client's parents, to start the therapy, to be actively involved in the therapy, as well as desiring to change their behavior (Drieschner et al., 2004; Reich, Bockel, \& Mewes, 2015). Therapeutic motivation can predict the success of the therapy and can predict premature termination (Reich et al., 2015).

Becker, Lee, Daleiden, Lindsey, Brandt \& Chorpita (2015) describe treatment participation as three things: 1) treatment attendance (presence in therapy), 2) treatment adherence (adherence to advice or tasks given during therapy), and 3) cognitive preparation (understanding or readiness to undergo therapy), these three domains are the most basic needs of the effectiveness and efficiency of the therapy carried out. Treatment attendance refers to an agreement between therapy participants (parents, children, families) to do treatment according to a schedule, like being present in therapy, telephone sessions, or homes or schools visits (Nock \& Ferriter, 2005). Treatment adherence refers to the client's activeness, willingness, and involvement in performing behaviors expected to produce therapeutic results, such as a willingness to engage in role-playing with children or complete homework given by the therapist (Nock \& Ferriter, 2005). Client non-adherence during therapy can reduce the benefits of received therapy (Lee et al., 2019). In addition, there is also cognitive preparation referring to the client's expectations related to the results of therapy, attitudes towards therapy, motivation to change, and perceptions of pressure and resources owned (Becker et al., 2015).

Nock \& Photos (2006) explains three components of parental motivation to participate in therapy for children, including the desire for children to change, parents' readiness to change parenting style, and parents' perceptions of their ability to change parenting style.

Drieschner, Lammers, \& Van Der Staak (2004) stated that there are several variables related to therapeutic motivation:

1. Perceived suitability of the treatment includes client satisfaction with the method used, agreement regarding the goals of therapy, and the client's perception of the therapeutic relationship.

2. Perceived costs of the treatment include the fee of the therapy sessions performed, lifestyle changes, and pressure from the environment.

3. Perceived external pressure includes pressure from partners, parents, and the system around the client.

In addition to the three variables mentioned above, the expectations held by clients are also a factor that determines the level of motivation in therapy (Drieschner et al., 2004). It can be explained further using expectancy theory. According to Vroom (1964), this expectancy theory can be used to explain an individual's motivation to perform a particular behavior. This expectancy theory is a cognitive explanation of human behavior that involves individuals playing an active role in thinking and predicting images in their environment. Vroom states that individuals will continually evaluate the outcomes of their behavior and subjectively assess the likelihood of each behavior that will lead to outcomes variations. According to Vroom, 
individuals believe that there is a relationship between the effort they put in, the performance from the effort, and the feedback they receive from their effort and performance. In other words, individuals will be motivated if they believe that strong efforts will result in a good performance, so this good performance will allow them to get the expected results.

Existing research in Indonesia about parental motivation discusses more in the education field (Aryanti, 2015; Nudin, Abdurakhman, \& Indra, 2020). In the clinical field, there are several studies about the correlation between parental motivation and other variables (Ananda, 2016; Asmika, Andarini, \& Rahayu, 2006), but nothing has been done to look deeper at the parents' motivation, especially for participating in child-administered therapy. It is crucial to discover so later can predict the success of therapy and to identify clients who have the potential to not participate in therapy. Furthermore, the overview obtained can be followed by developing separate interventions to increase the parents' motivation to participate in the therapy that the child undergoes so it is expected to reduce the rate of premature termination of child therapy. Based on the explanation above, it is interesting for the authors to find an overview of the parents' motivation to participate in their child's therapy.

\section{Method}

\section{Research Design}

This research was conducted using a qualitative approach exploratory study aimed to obtain a new understanding of a phenomenon based on data obtained in the field. The data collection techniques used structured interviews. The questions asked to the participants were open-ended questions based on the three dimensions of parents' motivation to participate in therapy proposed by Nock \& Photos (2006).

Interviews were conducted with 3 (three) parents of children aged 3-5 years who are undergoing therapy. Participants were selected using purposive sampling with the following criteria: (1) had undergone therapy for at least one month; and (2) come from the same socioeconomic class. The interview was only conducted with the mother, considering that the mother was more involved in providing therapy to children (Fitriani, 2020). In this study, there is no restriction on the problems experienced or the age range of the children.

The research was conducted in a psychology bureau in Bandung. The bureau uses a brain gym approach as an intervention for children, this approach at least requires the repetition of brain gym movements at home by parents, so parental participation to get maximum results is important. To do research on the bureau, the researcher sent a letter of application for permission first. After obtaining permission, the bureau provides recommendations on which client's parents can be interviewed. Then the researcher met the respondents to give informed consent and conducted interviews while the parents were waiting for their children to undergo therapy. During the interview, the researcher used tools in the form of a voice recorder and writing instruments.

\section{Results and Discussion}

\section{Result}

The following is a description of the respondents who were interviewed.

Table 1. Description of Respondents

\begin{tabular}{llll}
\hline & Respondent 1 & Respondent 2 & Respondent 3 \\
\hline Age & 36 years old & 23 years old & 28 years old \\
Education & S1 & S3 & S1 \\
Work & Housewife & Lecturer & Advocate \\
Child's age & 3 years old & 5 years old & 4 years old \\
Problem & Emotion & Speech Delay & Speech Delay \\
Duration of therapy & 5 months & 1 month & 1 month \\
Therapy schedule & $1 x /$ week $\quad$ (previously & 2x/week & $2 x /$ week \\
& $2 x /$ week) & & \\
\hline
\end{tabular}


Regarding the description of the respondents in Table 1, the three respondents are parents who are in the early adulthood age range, while the three children are in the early childhood age range. In addition, there are similarities between Respondent 2 and 3. Both bring their children to therapy with the same speech delay problem. Both also undergo therapy with the same schedule of two meetings per week. In contrast to Respondent 1 whose child undergoes therapy for one meeting per week for her child's emotional problems. Respondent 1 is undergoing a second therapy session, wherein the previous therapy session Respondent 1 also asked to do therapy for two meetings per week similar to Respondent 2.

Table 2. Interview Results

\begin{tabular}{|c|c|c|c|}
\hline & Respondent 1 & Respondent 2 & Respondent 3 \\
\hline $\begin{array}{l}\text { Therapeutic } \\
\text { Reason }\end{array}$ & $\begin{array}{l}\text { There is an urgent need to } \\
\text { improve immediately, } \\
\text { physically disturbing } \\
\text { - Recommended by friends. } \\
\text { - Have tried several places } \\
\text { before. } \\
\text { - Questioned by people } \\
\text { around. }\end{array}$ & $\begin{array}{l}\text { - } \quad \text { Delayed ability } \\
\text { - } \text { Recommended by } \\
\text { friends. } \\
\text { - It is recommended for } \\
\text { therapy by the school. } \\
\text { - Have tried several } \\
\text { places before. }\end{array}$ & $\begin{array}{l}\text { - It is recommended for } \\
\text { therapy by the school. } \\
\text { - Have tried several } \\
\text { places before. } \\
\text { - Feeling hurt because } \\
\text { the child is not } \\
\text { accepted by the } \\
\text { desired school. }\end{array}$ \\
\hline Hope & Can go back like before & Child can speak & Child can speak \\
\hline Expectation & Did not have expectation & $\begin{array}{l}\text { Imagined from the } \\
\text { previous therapy site }\end{array}$ & $\begin{array}{l}\text { Imagined from the } \\
\text { previous therapy site }\end{array}$ \\
\hline $\begin{array}{l}\text { Effects of } \\
\text { Therapy on } \\
\text { Children }\end{array}$ & $\begin{array}{l}\text { There has been more } \\
\text { progress than } \\
\text { expected. The child's } \\
\text { condition is better than } \\
\text { before. }\end{array}$ & $\begin{array}{l}\text { There is progress, } \\
\text { although not very } \\
\text { fluent. }\end{array}$ & $\begin{array}{l}\text { There is progress, } \\
\text { although not very } \\
\text { fluent. }\end{array}$ \\
\hline $\begin{array}{l}\text { Effects of } \\
\text { Therapy on } \\
\text { Mother }\end{array}$ & $\begin{array}{l}\text { - Gaining knowledge about } \\
\text { how to deal with children } \\
\text { - A positive response from } \\
\text { the environment. } \\
\text { - Feeling calmer. }\end{array}$ & $\begin{array}{l}\text { - Gaining } \\
\text { knowledge about how } \\
\text { to deal with children }\end{array}$ & $\begin{array}{l}\text { - A positive response } \\
\text { from the environment } \\
\text { - Feeling happy. } \\
\text { - Feeling the burden is } \\
\text { gone. } \\
\text { - Being more attentive } \\
\text { to children. }\end{array}$ \\
\hline $\begin{array}{l}\text { Views About } \\
\text { Therapy } \\
\text { Sessions }\end{array}$ & $\begin{array}{l}\text { - Suitable to the need. } \\
\text { Request } 2 \mathrm{x} \text { a week to } \\
\text { pursue the target to recover } \\
\text { quickly. }\end{array}$ & 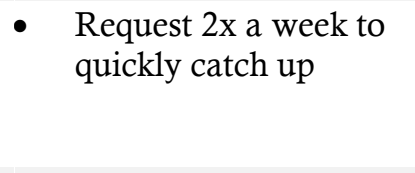 & - Suitable to the need. \\
\hline $\begin{array}{l}\text { Reasons to } \\
\text { Participate }\end{array}$ & $\begin{array}{l}\text { See the child's progress. } \\
\text { Feeling Sorry to see the } \\
\text { condition of the child }\end{array}$ & $\begin{array}{l}\text { - Want children to } \\
\text { change. } \\
\text { - Sorry to see the } \\
\text { condition of the child. }\end{array}$ & $\begin{array}{l}\text { - See the child's } \\
\text { progress. }\end{array}$ \\
\hline $\begin{array}{l}\text { Reasons to Do } \\
\text { Advice }\end{array}$ & $\begin{array}{l}\text { - Want to immediately see } \\
\text { the child's development } \\
\text { - } \quad \text { Visible results } \\
\text { Tried other advice but to } \\
\text { no avail } \\
\text { - Already prepared to receive } \\
\text { advice }\end{array}$ & $\begin{array}{l}\text { Want to immediately } \\
\text { see the child's } \\
\text { development }\end{array}$ & $\begin{array}{l}\text { Want to immediately } \\
\text { see the child's } \\
\text { development } \\
\text { - Visible results }\end{array}$ \\
\hline $\begin{array}{l}\text { Views of } \\
\text { Parent Ability }\end{array}$ & $\begin{array}{l}\text { - } \quad \text { Feeling capable. } \\
\text { - } \\
\text { udvice are easy to } \\
\text { understand \& do }\end{array}$ & $\begin{array}{l}\text { - } \quad \text { Feeling challenged } \\
\text { - } \\
\text { udvice are easy to } \\
\text { understand \& do }\end{array}$ & $\begin{array}{l}\text { - Feeling capable but } \\
\text { not optimal. }\end{array}$ \\
\hline Obstacle & $\begin{array}{ll}\text { - } & \text { Busy parents } \\
\text { - } & \text { Child's mood }\end{array}$ & $\begin{array}{ll}\text { - } & \text { Busy parents } \\
\text { - } & \text { Long distance } \\
\text { - } & \text { Not every advice have } \\
& \text { results immediately } \\
\end{array}$ & $\begin{array}{ll}\text { - } & \text { Busy parents } \\
\text { - } & \text { Forget }\end{array}$ \\
\hline
\end{tabular}


Based on the results of the interviews, it was found that the three respondents put their children in therapy because they felt the need to change their condition immediately. The three of them had tried several alternatives before but the results were not as expected. Finally, the three respondents took therapy on the advice they received from people around them, such as friends or the school.

The three respondents chose to participate in their child's therapy because they wanted to see changes in their children. Then after seeing that the therapy they undergo gave progress to the child's condition, this made the respondent more willing to continue to participate in the child's therapy, in this case, to continue to attend the therapy place according to the agreed schedule. Especially when the progress shown by the child exceeds the expectations of the respondent, as stated by Respondent 1 .

\section{Respondent 1}

"Karena ngeliat AZnya kali ya, maksudnya ke AZnya setiap pulang dari terapi dianya bawaannya happy, gitu."

(Because I saw AZ this time, I mean every time she came home from therapy, she was naturally happy, that's what it was.)

\section{Respondent 3}

"Ya liat kemajuan anak saya. Kalau saya juga, kalau nggak ada kemajuan ya ngapain, buang-buang uang. Makanya saya ngerasa ada kemajuan buat anak saya, ya makanya saya terus. Kalau anak saya masih gitu-gitu aja saya juga nggak akan nerusin."

(Yes, seeing my child's progress. For me too, if there is no progress there's no point, a waste of money. That's why I feel there is progress for my child, so I continue. If my child is still like that, I won't continue either.)

Apart from the effect seen on children, the three respondents also experiencing effects on themselves from their participation in child therapy. There is an increase in knowledge in dealing with children, feeling calmer and happier, and getting positive responses from the environment regarding the progress shown by children.

Interesting things were found in Respondent 1 and 2, where they felt an urgent need to see changes in their children. Therefore, both choose more frequent therapy sessions hoping for rapid changes in the child.

\section{Respondent 1}

"Awalnya kan untuk yang sampe 12 sesi itu seminggu $2 x$ saya ngambil, nah untuk yang sekarang ini seminggu sekali, kayanya ngobrol sama terapis juga ini seminggu sekali juga cukup, jadi nggak terlalu bolak-balik. Kalau yang sebelumnya 12 sih karena ngejar target pengen $A Z$ cepet pulih, itu udah ayo dikejar, sekarang udah agak kemajuannya pesat kayanya seminggu sekali ini cukup"

(Initially, for those 12 sessions, I took them twice a week, now once a week. After talking to the therapist, she also says once a week is enough, so there's no need to go back and forth. If the previous 12 were due to chasing the target of wanting AZ to recover quickly, so we go after it, now the progress is rather fast, I think once a week is enough)

\section{Respondent 2}

"Waktu itu tuh dikasih jatah hanya sekali, seminggu sekali. Cuman akunya minta 2 kali biar cepet, terus kebetulan ada jadwalnya".

(At that time, the schedule was only given once, once a week. But I asked twice a week to make it fast, and there happened to be a schedule.)

In addition to regularly attending therapy according to the agreed schedule, the three respondents also obeyed the advice given by the therapist. The reason is that they want to see the development and progress of children. Just like attendance, parental compliance in accomplishing the therapist's advice is increasing after seeing progress in the child, parents also feel that the advice given by the therapist is suitable with the needs of their child so that parents are willing to follow this advice further. The three respondents perceived that they were able to accomplish the given advice, although there were still obstacles faced in implementing them. 


\section{Discussion}

Based on the interviews, there are various reasons that parents have to include their children in therapy, these reasons can come from themselves (internal) or the environment (external-recommendations from others, complaints from school, family, friends, and other people around the child). It is as stated by Mash \& Wolfe (2016), adults often seek help to overcome children's problems due to concerns from adultsparents, teachers, school counselors, not because of the child's wishes. These problems include the children's failure to meet the age expected developmental tasks, although the problematic behavior that is complained of is not necessarily included in the abnormal category, therefore in children, an intervention is needed to encourage better development than only eliminating the complained problems (Mash \& Wolfe, 2016). It is in line with the statement of the three respondents who get their children in therapy to develop their children's abilities to be more optimal in age-expected development.

The interview results show an urgent need to immediately change the child's condition as a source of motivation for parents to continue to participate and attend regularly in the therapy activities undertaken by the child is as stated by Nock \& Photos (2006). Parents feel that their children's problems need to be overcome immediately because it could lead to more severe problems.

\section{Respondent 1}

"Pemicunya karena mendesak kali ya? Masalahnya makin hari makin ngedrop AZnya juga, karena kurang istirahat, terganggu istirahatnya, terus ke orang asing makin.. gimana gitu."

(The trigger is because of urgency, huh? The problem is that the AZ is dropping more and more every day, due to lack of rest, disturbed rest, and more and more strangers... how about that.)

\section{Respondent 2}

"Tadinya mah intinya ingin bisa ngomong, kan telat, telat banget bicaranya. Tapi setelah diobservasi katanya masih banyak okupasinya, jadi akhirnya semuanya mungkin harus diterapi"

(At first, I wanted to be able to talk, it was too late, it was too late to talk. But after being observed, he said there were still many occupations, so in the end, all of them might have to be treated)

The need for the child's condition to change immediately is related to the severity of the problem. Previous research has also stated that the severity of the problems children have is related to the individual's motivation for therapy (Reich et al., 2015).

Based on variables related to motivation according to Drieschner, et al. (2004), namely perceived suitability of the treatment which includes client satisfaction with the method used, agreement regarding the goals of therapy, and client's perception of the therapeutic relationship established. The three respondents were satisfied with the method used so they continued to get their child in brain gym therapy, it can be seen from the experience of the three respondents who had previously tried several alternatives before finally choosing the current therapy method. In addition, the parents' belief that there will be changes in their children by undergoing the therapy significantly predicts the presence of parents because they perceive that the therapy is beneficial so that they are more likely to bring their children back to therapy (Lee et al., 2019). Belief in the influence of therapy affects the client's motivation to comply in undergoing therapy (Gill et al., 2014). More specifically, Respondent 3's statement describes parents' satisfaction with the methods used in current therapy settings, which tend to be transparent, parents were informed about their children's activity in therapy centers and what parents should do at home.

Regarding the client's agreement on the therapy goals, it can be illustrated by the statements from Respondents 1 and 2. Both have changed from the intended outcomes of the therapy. Respondent 1 initially took her child to therapy aimed to solve emotional problems, but after one therapy session was completed Respondent 1 also agreed with the therapist that they would continue with the next therapy session to improve her child's speech ability. On the other hand, Respondent 2 came to a psychologist intending to improve her child's speech ability but finally agreed to do therapy to first improve other developmental aspects that are considered more basic before finally improving the child's speech ability. It shows that the three respondents feel that the therapy is suitable for the problems they have. 
Furthermore, related to the client's perceived cost of the treatment, which includes the cost of the therapy sessions carried out, lifestyle changes, pressure from the environment that does not approve of the implementation of therapy (Drieschner et al., 2004). Respondent 1's statement describes the pressure from people around her who still considers that psychological services are only for people with mental problems. So, for Respondent 1 , there is a perceived burden and need to be overcome first to be able to follow therapy. Meanwhile, Respondent 3 views the costs of the therapy they are undergoing.

\section{Respondent 3}

"Ya liat kemajuan anak saya. Kalau saya juga, kalau nggak ada kemajuan ya ngapain, buang-buang uang. Makanya saya ngerasa ada kemajuan buat anak saya, ya makanya saya terus. Kalau anak saya masih gitu-gitu aja saya juga nggak akan nerusin." (Responden 3).

(Yes, seeing my child's progress. For me too, if there is no progress there's no point, a waste of money. That's why I feel there is progress for my child, so I continue. If my child is still like that, I won't continue either.)

The external pressure perception variable includes pressure from partners, parents, and the system around the client (Drieschner et al., 2004). It is as experienced by Respondent 3 whose child was rejected by one of the schools, so he was encouraged to include his child for therapy.

\section{Respondent 3}

"Terus kemarin kan mau daftar TK eh taunya nggak diterima karena anaknya memang tidak kompeten buat sekolah, duh disitu saya marah banget, emang anak saya kenapa kok sekolah sampai nggak nerima. Makanya saya langsung diarahin sama sekolahnya itu untuk kesini, akhirnya saya konsultasi dll."

(Then yesterday I wanted to register for kindergarten, but when I know he was not accepted because the child is not competent to make school, duh, I was very angry there, why did my child was not accepted in school. I was immediately recommended by the school to come he, I finally consulted and more)

Aside from the client's perception of therapy, there are also client expectations (Drieschner et al., 2004) explained by Vroom's (1964) expectancy theory. In this case, if the parents believe that the efforts they make to participate in the therapy, have a relationship with the effectiveness of the therapy that can then produce the results they expect, namely the resolution of this problem. If it is linked to the respondents' statements, all three of them have the same expectation. If they make an effort by regularly coming to the therapy center and are willing to do the advice given by the therapist, the respondent will be able to get the expected results. Including if the effort made is greater, the respondent believes that the success they will get is greater as well. It can be seen from what was done by Respondents 1 and 2 who requested that their children be scheduled for more frequent therapy to get a rapid change in their children's behavior.

To be able to explain the parents' motivation to maintain participatory behavior in therapy, we can use the operant conditioning theory proposed by BF Skinner, where an aspect can strengthen the emergence of behavior, which is called reinforcement (Gordan \& Krishanan, 2014; Miltenberger, 2016). The existence of expected progress shown by the child after the parent begins to try to participate in therapy becomes a positive reinforcement that strengthens the parents' behavior to continue to actively participate in therapy. In addition, a positive response from the environment related to the child's progress also becomes positive reinforcement for parents that makes parents keep diligently coming to the therapy center and willing to follow the advice given by the therapist. On the other hand, the reduced problem behavior that parents complain about becomes negative reinforcement that also increases the willingness of parents to participate in child therapy.

An interesting finding was obtained from Respondent 1's statement. Before she took her child to a therapy center, she first took her child to a shaman because she was worried that her child's problems were caused by supernatural disturbance.

\section{Respondent 1}

"Sebelum ke psikolog ini ke ini dukun hehe.. ke alternatif dulu kaya nyoba dulu itu, terus ternyata, nggak ada gangguan jin atau apa gitu, udah dicoba baca doa segala nggak ngaruh. Ngobrol lah sama temen, terus temen ngasih solusi katanya ada temen dia juga, sodara dia juga, sepupu katanya mirip $A Z$ 
cuma beda itu.. coba ke psikolog aja. Akhirnya konsultasi ke psikolog, ternyata kemungkinan sih ada pemicunya gitu, makanya dicoba terapi kendali emosi. Setelah beberapa kali udah keliatan sih hasilnya"

(Before going to this psychologist, I went to this shaman hehe .... to the alternative, I tried that first, then it turned out that there was no jinn disturbance or anything like that. After chatting with friends, the friends give solutions, they say there are their friends too, their cousins, who are similar to AZ, only that's different... Just try going to a psychologist. Finally, I consulted with the psychologist, it turned out that there might be a trigger, so I tried emotional control therapy. After a few times, the results are visible.)

This statement from Respondent 1 corresponding with research from Reich, Bockel \& Mewes (2015) which states that a person's motivation in psychotherapy is related to the individual's belief in supernatural things which can then reduce the individual's level of motivation to attend therapy. The client's beliefs can make them reluctant to follow psychological therapy and prefer alternative treatments. These beliefs need to be recognized in the implementation of therapy to ensure that the therapy carried out has a positive effect. In addition, based on the statement of Respondent 1 , it is known that there is still a stigma circulating in the community regarding psychologists who are only seen to deal with severe mental problems.

\section{Respondent 1}

"Mikirnya tuh kalau ke psikolog tu yang terganggu. gangguan kejiwaan. Tapi sebelum kesini juga kan googling dulu, baca-baca dulu"

(I think that if you go to a psychologist, it's a mental disorder. But before coming here, I google it first, read it first)

It shows that the client's ignorance of psychological therapy raises doubts about participating. In line with this, it is known that there is a correlation between motivation and knowledge about the intervention undertaken (Ananda, 2016; Anwar, Wihastuti, \& Suharsono, 2014; Asmika et al., 2006).

\section{Conclusion}

The results showed that the t-count value was 2.329, found t-table at a significance level of (0.05) of 2.021, which means t-table < t-count which means that youtube as a classical guidance media affects students' learning motivation during the COVID-19 pandemic. These results show that there is a significant difference in the increase in learning motivation in the experimental group who were given classical guidance services using youtube as a service medium and the control group who did not use youtube as a service medium. Classical guidance media in the form of youtube has several advantages over other classical guidance service media, including by using youtube as a learning media, students are more interested and enthusiastic in participating in classical guidance services. Apart from this, this study still has not yet perfect, including the research design used by the researcher where the researcher uses a true experimental design using a posttest only control group design. Researchers hope that in the future this research can be developed so that it can complement this research.

\section{References}

Ananda, Y. (2016). Hubungan Pengetahuan dan Motivasi dengan Keterlibatan Orang Tua dalam Terapi Perilaku pada Anak Autis di SLB YPPA Padang Tahun 2016. The Shine Cahaya Dunia S-1 Keperawatan, 1(1).

Anwar, S., Wihastuti, T. A., \& Suharsono, T. (2014). Hubungan Tingkat Pengetahuan Tentang Program Terapi Metadon dengan Tingkat Motivasi Mengikuti Program Terapi Rumatan Metadon pada Pengguna Narkoba Suntik di Puskesmas Kecamatan Grogol Petamburan Jakarta Barat. Majalah Kesehatan FKUB, 1(1), 24-38. $\quad$ Retrieved from http://majalahfk.ub.ac.id/index.php/mkfkub/article/viewFile/20/17\%0Ahttp://majalahfk.ub.ac.i d/index.php/mkfkub/article/view/20/17

Aryanti, Y. (2015). Motivasi Orang Tua Memasukkan Anaknya ke Taman Kanak-Kanak. Universitas Pendidikan Indonesia. 
Asmika, Andarini, S., \& Rahayu, R. P. (2006). Hubungan Motivasi Orangtua Untuk Mencapai Kesembuhan Anak dengan Tingkat Pengetahuan Tentang Penanganan Anak Penyandang Autisme dan Spektrumnya. Jurnal Kedokteran Brawijaya, 22(2), 90-94. https://doi.org/10.21776/ub.jkb.2006.022.02.6

Becker, K. D., Lee, B. R., Daleiden, E. L., Lindsey, M., Brandt, N. E., \& Chorpita, B. F. (2015). The Common Elements of Engagement in Children's Mental Health Services: Which Elements for Which Outcomes? Journal of Clinical Child and Adolescent Psychology, 44(1), 30-43. https://doi.org/10.1080/15374416.2013.814543

Centers for Disease Control and Prevention. (2019). Data \& Statistics on Children's Mental Health. Retrieved April 19, 2019, from https://www.cdc.gov/childrensmentalhealth/data.html

Drieschner, K. H., Lammers, S. M. M., \& Van Der Staak, C. P. F. (2004). Treatment motivation: An attempt for clarification of an ambiguous concept. Clinical Psychology Review, 23(8), 1115-1137. https://doi.org/10.1016/j.cpr.2003.09.003

Fitriani, A. (2020). Fenomena Kesehatan Perkembangan Seksual dan Peran Orang Tua Mild Retardation dalam Pendidikan Seks. Psychopedia Jurnal Psikologi Universitas Buana Perjuangan, 5(1), 28-46. https://doi.org/10.36805/psychopedia.v5i1.1004

Gill, L., Cassia, F., Cameron, I., Kurrle, S., Lord, S., Fairhall, N., ... Langron, C. (2014). Exploring client adherence factors related to clinical outcomes. Australasian Marketing Journal, 22(3), 197-204. https://doi.org/https://doi.org/10.1016/j.ausmj.2014.08.006

Gordan, M., \& Krishanan, I. A. (2014). A Review of B. F. Skinner's 'Reinforcement Theory of Motivation. International Journal of Research in Education Methodology, 5(3), 680-688.

Kazdin, A. E., Holland, L., \& Crowley, M. (1997). Family experience of barriers to treatment and premature termination from child therapy. Journal of Consulting and Clinical Psychology, 65(3), 453-463. https://doi.org/10.1037/0022-006X.65.3.453

Koran Jakarta. (2017, December 31). 50 Persen Anak Mengalami Gangguan Mental. Retrieved from http://www.koran-jakarta.com/50-persen-anak-mengalami-gangguan-mental/

Krause, M. S. (1966). A cognitive theory of motivation for treatment. Journal of General Psychology, 75(1), 9-19. https://doi.org/10.1080/00221309.1966.9710345

Lee, P., Zehgeer, A., Ginsburg, G., McCracken, J., Keeton, C., PC, K., ... Compton, S. (2019). Child and Adolescent Adherence With Cognitive Behavioral Therapy for Anxiety: Predictors and Associations With Outcomes. Journal of Clinical Child and Adolescent Psychology, 48(sup1), S215-S226. https://doi.org/10.1080/15374416.2017.1310046

Mash, E. J., \& Wolfe, D. A. (2016). Abnormal Child Psychology (6th Editio). Boston: Cengage Learning. https://doi.org/10.4324/9780203893258

Miltenberger, R. G. (2016). Behavior Modification: Principles and Procedures (Sixth Edit). Boston: Cengage Learning.

Nock, M. K., \& Ferriter, C. (2005). Parent Management of Attendance and Adherence in Child and Adolescent Therapy: A Conceptual and Empirical Review. Clinical Child and Family Psychology Review, 8(2). https://doi.org/10.1007/s10567-005-4753-0

Nock, M. K., \& Photos, V. (2006). Parent Motivation to Participate in Treatment: Assessment and Prediction of Subsequent Participation. Journal of Child and Family Studies, 15(3), 345-358. https://doi.org/10.1007/s10826-006-9022-4

Nudin, M. I., Abdurakhman, O., \& Indra, S. (2020). Motivasi Orang Tua Memilih Pesantren Sebagai Sarana Pendidikan. E-Journal Skripsi: Fakultas Keguruan Dan Ilmu Pendidikan, 3(1), 14-27.

Pellerin, K., Costa, N., Weems, C., \& Dalton, R. (2010). An examination of treatment completers and noncompleters at a child and adolescent community mental health clinic. Community Mental Health Journal, 46(3), 273-281. https://doi.org/10.1007/S10597-009-9285-5

Reich, H., Bockel, L., \& Mewes, R. (2015). Motivation for Psychotherapy and Illness Beliefs in Turkish Immigrant Inpatients in Germany: Results of a Cultural Comparison Study. Journal of Racial and Ethnic Health Disparities, 2(1), 112-123. https://doi.org/10.1007/S40615-014-0054-Y

Vroom, V. H. (1964). Work and motivation. Wiley.

Wierzbicki, M., \& Pekarik, G. (1993). A Meta-Analysis of Psychotherapy Dropout. Professional Psychology: Research and Practice, 24(2), 190-195. https://doi.org/10.1037/0735-7028.24.2.190 
The authors declare that they have no significant competing financial, professional or personal interests that might have influenced the performance or presentation of the work described in this manuscript.

First Publication Right: BISMA The Journal of Counseling

https://doi.org/10.xxxx/ $x x x x x$

Open Access Article | CC-BY Creative Commons Attribution 4.0 International License.

Word Count: 